\title{
Concurrent methylation and demethylation of arsenic in fungal cells
}

\author{
S.M. Su, X.B. Zeng, L.Y. Bai, Y.N. Wang \& C.X. Wu \\ Institute of Environment and Sustainable Development in Agriculture, Chinese Academy of Agricultural Sciences/Key \\ Laboratory of Agro-Environment, Ministry of Agriculture, Beijing, P.R. China
}

\begin{abstract}
Microbial methylation and demethylation are central to arsenic's (As) biogeochemical cycling. Here, the transformations of monomethylarsonic acid (MMA(V)) $\left(50 \mathrm{mg} \mathrm{L}^{-1}\right)$ for 15 days in cells of As-methylating fungi, Fusarium oxysporum CZ-8F1, Penicillium janthinellum SM-12F4, and Trichoderma asperellum SM-12F1, were evaluated, and trace concentrations of $\mathrm{As}(\mathrm{III})$ and $\mathrm{As}(\mathrm{V})$ were observed in fungal cell extracts. Trace amounts of DMA(V) were also detected in MMA(V) and P. janthinellum SM-12F4 incubations. In situ X-ray absorption near edge structure (XANES) indicated that after exposure to $\mathrm{MMA}(\mathrm{V})\left(500 \mathrm{mg} \mathrm{L}^{-1}\right)$ for 15 days, $28.6-48.6 \%$ of accumulated As in fungal cells was DMA(V), followed by $18.4-30.3 \%$ from As(V), 0-28.1\% from As(III), and 4.8-28.9\% from MMA(V). The concurrent methylation and demethylation of As occurs in fungal cells. The findings of this study will develop our understandings of microorganisms that drive As speciation transformation.
\end{abstract}

\section{INTRODUCTION}

Microbial methylation and volatilization of arsenic (As) drives As biogeochemical cycling ecosystems. Notably, organic matter, moisture, and $\mathrm{pH}$ all regulate As methylation and volatilization. Demethylation of methylarsenicals has been also widely studied in soils. However, there are very limited studies associated with As demethylation in microbial cells. Furthermore, some As-methylating microorganisms are capable of demethylation of methyarsenicals. NsarsI cloned from As-methylating Nostoc sp. PCC 7120 encodes a C.As lyase responsible for MMA(III) demethylation (Yan et al., 2015). However, whether methylation and demethylation can be triggered concurrently in the same microbial cell remains unknown. Three fungal strains, $F$. oxysporum $\mathrm{CZ}-8 \mathrm{~F} 1, P$. janthinellum SM-12F4, and $T$. asperellum SM-12F1, were shown to be capable of As(III) or As(V) methylation, with $\mathrm{MMA}(\mathrm{V})$ and $\mathrm{DMA}(\mathrm{V})$ generated as products $(\mathrm{Su}$ et al., 2012). In this study, after exposure to MMA(V), As speciation transformation in F. oxysporum CZ-8F1, $P$. janthinellum SM-12F4, and T. asperellum SM-12F1 cells was evaluated using in situ X-ray absorption spectroscopy (XAS) and ion exchange chromatographic separation.

\section{METHODS/EXPERIMENTAL}

\subsection{As speciation in fungal culture system using ion} exchange chromatography separation

Briefly, after incubation with the fungal spore suspension $\left(0.2 \mathrm{~mL}, 10^{4} \mathrm{cfu} \mathrm{mL}^{-1}\right)$ in potato-glucosepeptone (PGP) medium (spiked with MMA(V) of
$50 \mathrm{mg} \mathrm{L}^{-1}$ ) for $1,3,5,10$, and 15 days, the culture medium was removed via centrifugation $(12,000 \mathrm{~g}, 15 \mathrm{~min})$. A mixture of buffer solution $\left(0.1 \mathrm{M} \mathrm{KH}_{2} \mathrm{PO}_{4} / \mathrm{K}_{2} \mathrm{HPO}_{4}, \mathrm{pH} 7.0,10 \mathrm{~mL}\right)$ and ultrapure water $(10 \mathrm{~mL})$ was used to wash the compact fungal cells. Arsenic speciation in fungal cells was extracted using tetramethylammonium hydroxide (TMAH, 25\%, $0.3 \mathrm{~mL})$ and ultrapure water $(4.7 \mathrm{~mL})$ by grinding, centrifugation $(12,000 \mathrm{~g}, 15 \mathrm{~min})$, and filtration (diameter, $0.20-\mu \mathrm{m}$ ). Arsenic speciation analysis was conducted using high performance liquid chromatography-hydride generation-atomic fluorescence spectrometry (HPLC-HG-AFS, SA-10, Titan Instruments, Beijing, China). PGP medium spiked with $\mathrm{MMA}(\mathrm{V})$ and without fungi was used to investigate the natural variance of MMA(V). Three replicates were run for each sampling time. No As was detected in the spore suspension used as the fungal inoculum.

\subsection{As speciation in fungal cells using in-situ XAS}

Fungal cells were harvested after cultivation for 15 days in PGP medium spiked with $500 \mathrm{mg} \mathrm{L}^{-1} \mathrm{MMA}(\mathrm{V})$ $\left(\mathrm{CH}_{4} \mathrm{AsNaO}_{3}\right.$, Strem Chemicals, Inc. Newburyport, USA). Sample preparation and analysis using X-ray absorption near edge structure (XANES) was performed as previously reported (Su et al., 2012). For As distribution mapping using X-ray fluorescence (XRF), each point was scanned for $2 \mathrm{~s}$ using a silicon/lithium $(\mathrm{Si} / \mathrm{Li})$ detector with a spot size of $3.08 \times 2.78 \mu \mathrm{m}^{2}$ and a step size of $5 \mu \mathrm{m}$. For As speciation determination using XANES, each site was scanned for $6 \mathrm{~s}$ using a spot size of $3.08 \times 2.78 \mu \mathrm{m}^{2}$ from 11,850 to $11,920 \mathrm{eV}$ with a $0.5 \mathrm{eV}$ step size. During XANES 
analysis, As standard compounds were prepared with high-purity ( $>94.5 \%$ ) chemicals.

\section{RESULTS AND DISCUSSION}

\subsection{As speciation in fungal cells using ion exchange chromatographic separation}

MMA(V), a small amount of inorganic As, and $\mathrm{DMA}(\mathrm{V})$ were observed in fungal cells after being exposed to MMA(V). MMA(V) contents in the fungal cells initially increased and then decreased with cultivation time. Furthermore, a small amount of As(III), $\mathrm{As}(\mathrm{V})$, or $\mathrm{DMA}(\mathrm{V})$ were also observed in fungal cells. For T. asperellum SM-12F1, the converse varying trends for $\mathrm{As}(\mathrm{III})$ and $\mathrm{As}(\mathrm{V})$ were observed with time. When cultivation time was prolonged to 15 days, the contents of $\mathrm{As}(\mathrm{III})$ and $\mathrm{As}(\mathrm{V})$ were 0.6 and $3.8 \mu \mathrm{g} \mathrm{g}^{-1}$, respectively. For $P$. janthinellum SM- $12 \mathrm{~F} 4$, DMA(V) of 0.4 and $28.7 \mu \mathrm{g} \mathrm{g}^{-1}$ at a cultivation time of 2 and 3 days was observed, respectively. As(III) and $\mathrm{As}(\mathrm{V})$ contents reached 1.5 and $0.9 \mu \mathrm{g} \mathrm{g}^{-1}$ when the cultivation time extended to 15 days, respectively. For F. oxysporum CZ-8F1, As(III) and $\mathrm{As}(\mathrm{V})$ of 0.3 and $1.2 \mu \mathrm{gg}^{-1}$ were observed at a cultivation time of 15 days, respectively. This indicates that MMA(V) demethylation into $\mathrm{As}(\mathrm{III})$ and $\mathrm{As}(\mathrm{V})$ and methylation into DMA occurred in fungal cells after exposure to MMA(V) (data see Su et al., 2017).

\subsection{As speciation in fungal cells using in-situ XAS}

Arsenic accumulation in fungal cells was easily observed using XRF, as shown in Figure 1, after exposure to $500 \mathrm{mg} \mathrm{L}^{-1}$ of $\mathrm{MMA}(\mathrm{V})$ for 15 days. The XANES spectra for each fungal strain and the standards are shown in Figure 1D. Evaluation of the XANES spectra beyond the absorption edge shows differences in the $11,862-11,875 \mathrm{eV}$ regions of the three fungal strains. DMA(V) and inorganic As were simultaneously observed in fungal cells after MMA(V) exposure. For T. asperellum SM-12F1, 48.6\% of the accumulated As was DMA(V), followed by $28.1 \%$ As(III), $18.4 \% \mathrm{As}(\mathrm{V})$, and $4.8 \% \mathrm{MMA}(\mathrm{V})$. For $P$. janthinellum SM-12F4, $41.1 \%$ of the accumulated As was DMA(V), followed by $30.3 \% \mathrm{As}(\mathrm{V})$, and $28.9 \%$ MMA. No As(III) was observed. However, for F. oxysporum $\mathrm{CZ}-8 \mathrm{~F} 1,29.0 \% \%$ of the accumulated As was As(V), followed by $28.6 \% \operatorname{DMA}(\mathrm{V}), 26.3 \%$ MMA(V), and $16.2 \%$ As(III). MMA(V) remethylation and demethylation could be simultaneously triggered in fungal cells (data see Su et al., 2017).

The concurrent methylation and demethylation of As may exist in fungal hyphae. The concurrent methylation and demethylation of As is supported by our observations using the ion exchange chromatographic separation and in situ XANES. Comparatively, XANES analysis over-estimated the methylation of MMA(V). The differences between both methods might be attributed to: (I) As exposure condition, as higher As exposure might help to emerge the methylated arsenide in biological cells; (II) measurement
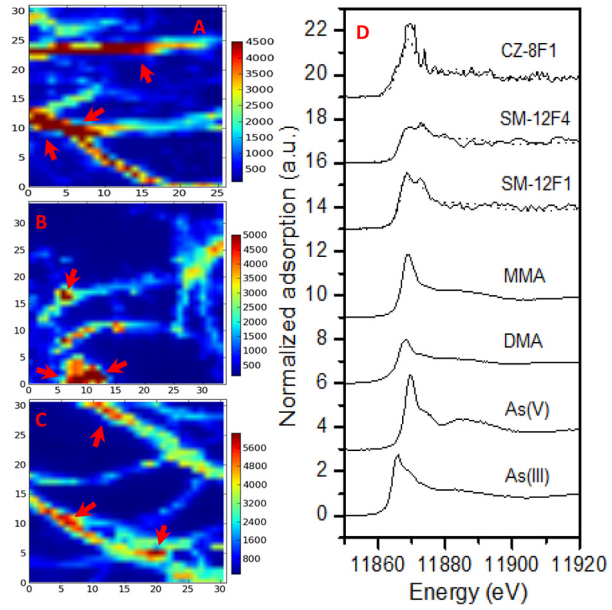

Figure 1. X-ray fluorescence (XRF) images and X-ray absorption near edge structure (XANES) spectra of three fungal strains after exposure to $500 \mathrm{mg} \mathrm{L}^{-1}$ of $\mathrm{MMA}(\mathrm{V})$ for 15 days. A, B, and C: XRF images for SM-12F1, SM-12F4, and $\mathrm{CZ}-8 \mathrm{~F} 1$; D, XANES spectra of four references and three fungal strains.

scales, XANES analysis is used to determine As species in a particular area of a sample. While the typical method produced the average value of As in samples; (III) sample preparation, since samples for XANES analysis are preserved in their native state. However, the mixed cellular sample is acquired by cellular lysis and centrifugation in advance of HPLCHG-AFS analysis. Notably, these differences do not interfere with our observation that the concurrent methylation and demethylation of As exists in fungal cells. The typical method coupled with in situ XANES is recommended to detect As species in samples.

\section{ACKNOWLEDGEMENTS}

The authors thank for financial support from the National Foundation of Natural Science of China, Grant No. 41671328, and the Yong Elite Scientist Sponsorship Program by the China Association for Science and Technology.

\section{REFERENCES}

Su, S.M., Zeng, X.B., Li, L.F., Duan, R., Bai, L.Y., Li, A.G., Wang, J. \& Jiang, S. 2012. Arsenate reduction and methylation in the cells of Trichoderma asperellum SM-12F1, Penicillium janthinellum SM-12F4, and Fusarium oxysporum $\mathrm{CZ}-8 \mathrm{~F} 1$ investigated with X-ray absorption near edge structure. J. Hazard. Mater. 243: 364-367.

Su, S.M., Zeng, X.B., Bai, L.Y., Wang, Y.N., Zhang, L.L., Li, M.S. \& Wu, C.X. 2017. Concurrent methylation and demethylation of arsenic by fungi and their differential expression in the protoplasm proteome. Environ. Pollut. 225: 620-657.

Yan, Y., Ye, J., Xue, X.M. \& Zhu, Y.G. 2015. Arsenic demethylation by a C.As lyase in cyanobacterium Nostoc sp. PCC 7120. Environ. Sci. Technol. 49: 14350-14358. 